\title{
Governing Closing Basins: The Case of the Gediz River in Turkey
}

\author{
Mark Svendsen \\ Consultant, Philomath, Oregon, USA \\ D. Hammond Murray-Rust \\ International Water Management Institute, Colombo, Sri Lanka \\ Nilgün Harmancroğlu \\ and Necdet Alpaslan \\ Dokuz Eylul University, Faculty of Engineering, \\ Tinaztepe Campus, Buca, Izmir, Turkey
}

\begin{abstract}
The Gediz is a closing basin with little new water available for allocation. It is not, however, a mature basin, in the sense that the institutional set-up is not yet fully developed. Both surface and groundwater use are largely unregulated, and groundwater extraction is growing rapidly in response to urban and, particularly, industrial demand. There is no functional system of allocating rights to either surface or ground water. The most serious current problem, however, is deteriorating water quality in the Gediz and its tributaries resulting from urban and industrial wastewater discharges and, to a lesser extent, agricultural return flows.
\end{abstract}

Two public agencies are responsible for in-stream and wastewater quality monitoring, but neither has enforcement powers. These are concentrated in a third party in each province-the provincial governor. Governors are subject to competing pressures and are generally unable to mount effective enforcement programmes. Responsibilities for basin planning and monitoring are compartmentalised, broken out into dimensions of ground and surface water on one hand, and quantity and quality on the other. Co-ordination among the responsible units is limited.

Ultimately the roots of the water quality problem are political in nature, as there is presently a severe imbalance in power among the various involved partiesindustry, municipalities, agriculture, and the environment. The environment, in particular, is underrepresented and an internationally-recognised bird sanctuary at the mouth of the Gediz currently receives only extremely limited quantities of poor quality water during the summer months.

Solutions to these problems involve systematising water rights, developing coordinating mechanisms among managers, involving the private sector in wastewater treatment, and the emergence of an effective NGO-based advocacy for environmental concerns in the basin.

\section{Introduction}

The Gediz basin in western Turkey (Figure 1) has changed considerably in the past decade, moving from being a comparatively water-rich basin to one that is 
Figure 1: Location of Gediz basin

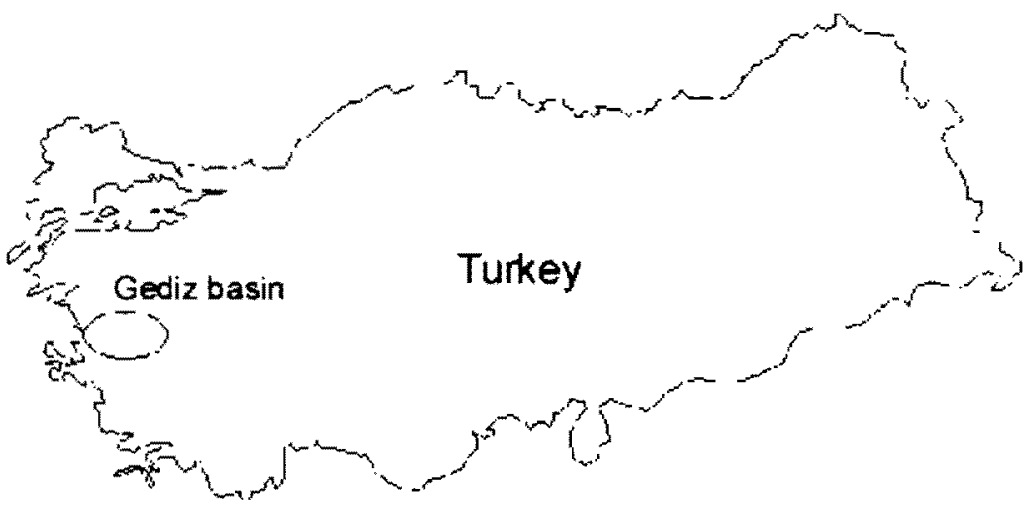

now closing'. This change has been in part a result of a severe drought that affected the basin from 1989 to 1994 , in part due to an above average increase in urban and industrial demand, and in part due to a rapidly growing concern for issues of water quality and environmental protection. Paralleling these hydrologic changes has been a much slower institutional response that has not kept up with the requirements for changes in the way water is allocated and managed.

The basin is currently caught up in a very dynamic period of reassessment and change which began with the onset of drought in 1989. Before the drought, there was little competition for water, and the established mechanism for allocating water to different users through a set of bilateral agreements worked well. The only serious conflicts were internal to Irrigation systems where there were disagreements between the state Hydraulics Works Organisation (DSI) and water users.

When the drought struck, water issues for irrigation in the peak summer season were reduced sharply, return flows diminished, and, as a consequence, water quality in the lower third of the basin deteriorated. Rural residents began to complain that water was unsuitable for irrigation. At the same time there was widespread desiccation of the important welland areas in the Gediz delta, leading to large reductions in bird populations and, possibly, loss of species diversity.

Although the drought has now passed, the legacy is seen in a number of important issues that continue to lie at the core of the debates surrounding the management of water in the Gediz basin. Several of these are highlighted below and discussed in more detail in the remainder of the paper.

${ }^{1}$ A closed basin is one in which there is no unused water left to be allocated. 
- The increasingly apparent need for a unified co-ordinating mechanism for allocating water among irrigation, urban demand, industrial requirements and environmental protection to replace existing bilateral processes.

- The continuing struggle between older long-established institutions dealing with water resource development and water allocation, and emerging institutions concerned primarily with water quality and environmental issues.

- The need to represent and protect the interests of certain water users, such as the Gediz delta ecology and the Irrigation Associations established during the past five years to assume responsibility of operation and maintenance for 110,000 hectares of large-scale irrigation systems, within the wider debate on water resources allocation and management.

- The need for clear rules assigning responsibility for setting water quality and quantity standards and monitoring actual conditions, and for sufficient political power and will to sanction violators of the standards.

In the remainder of the paper we deal first with the hydrology and water use patterns within the basin and then turn to the legal, policy, and institutional conditions which influence how the basin is governed and managed. Finally, we combine the two assessments to summarise the problems facing the basin and the challenges it must meet to overcome them. The economic and social context of Turkey is described briefly in Annex 1.

\section{Basin water use}

The Gediz basin contains a typical range of water users, although the balance among them has been changing during the past couple of decades. Each user category is described briefly hereunder.

\subsection{Irrigated agriculture}

Traditionally the largest user of water has been irrigated agriculture, originally deriving from small run-of-the-river diversions from the Gediz and its tributaries dating back some three thousand years. Since 1945 the development of largescale systems and groundwater exploitation have transformed irrigated agriculture.

\subsubsection{Large scale surface irrigation}

The first investments in modern irrigated agriculture began in 1945 with the construction of two large regulators to tap the flow of the Gediz River. Adala regulator serves some 20,000 hectares of land in the middle portion of the basin while Emiralem regulator commands 22,000 hectares in the Gediz delta (Figure 2). In the 1960s, a second set of investments were made that included the construction of Demirkopru 
Reservoir a few kilometres upstream of Adala, a third regulator at Ahmetli, and the regulation and raising of the natural lake of Gol Marmara. Ahmetli Regulator commands some 45,000 hectares of land. The final surface water developments took place in the Alasehir valley with the construction of two small reservoirs.

\section{Figure 2: Irrigation and drainage flow patterns, Gediz basin}

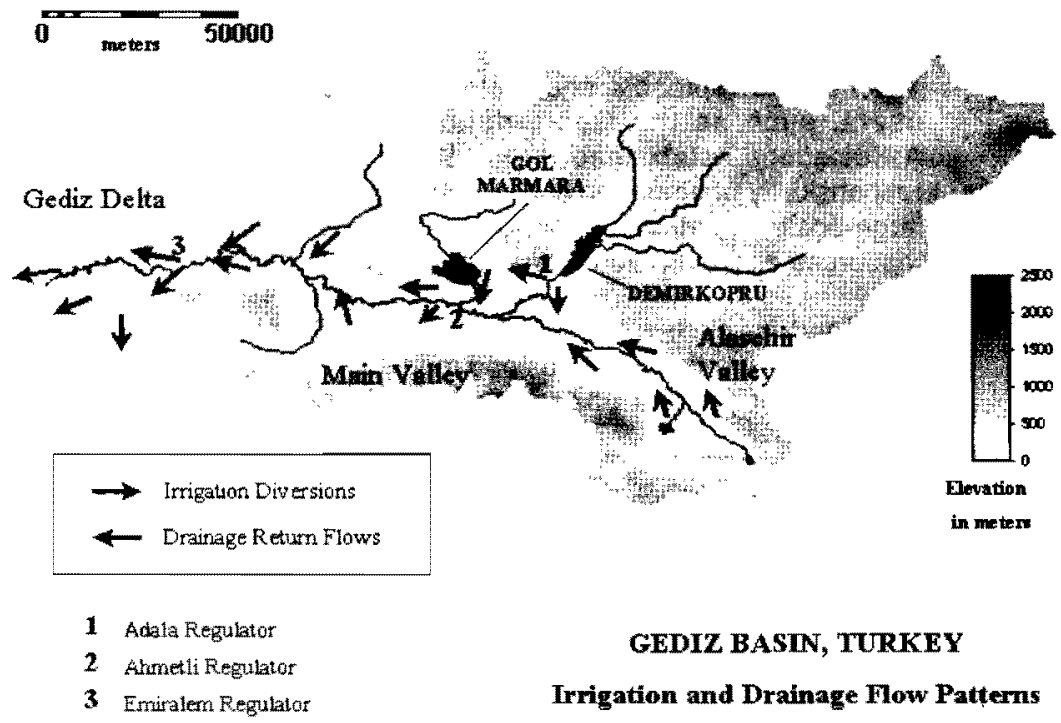

The total command area of the large-scale surface systems is approximately 110,000 ha. The predominant crops are cotton (50\%), grapes (35\%), maize, fruit orchards, and vegetables. At present surface water issues from Demirkopru are limited to the interval between mid-June and mid-September which is focused on the cotton growing season. Natural stream flows from tributaries can be used for land preparation for cotton or for early irrigation of grapes and fruit trees, but there are no releases made into the Gediz River from Demirkopru outside this period.

Water use in the 90,000 hectares of the central and delta zones is limited to 75 $\mathrm{m}^{3} / \mathrm{sec}$ from Demirkopru and $15 \mathrm{~m}^{3} / \mathrm{sec}$ from Gol Marmara for a release period of approximately 60 days, or a total of some 550 million cubic metres during the year. This is equivalent to some $450 \mathrm{~mm}$ of irrigation water for the growing season.

In the Alasehir Valley in the east of the basin, irrigation is aimost exclusively for grapes. Application rates are approximately $350 \mathrm{~mm} / \mathrm{season}$ and during the summer there is no significant nel outflow into the main part of the basin. It is estimated that, through a combination of surface application and some pumping of the shallow aquifer, approximately 60 million $\mathrm{m}^{3}$ are consumed during the summer season. 


\subsubsection{Small-scale surface irrigation}

In many tributary valleys into the Gediz there are small-scale surface water diversions that take advantage of winter run-off and spring snowmelt. Typical crops are fruit trees, winter wheat, and vegetables because these require water only in spring and early summer before the streams dry up.

There are no accurate records of the total area involved, but it almost certainly is more than 25,000 hectares since almost every village situated on the valley fringe has some irrigated area (Kayam and Svendsen, 1999). Because the number of irrigations is low, normally $2-4$ irrigations of about $50 \mathrm{~mm}$ each for the entire season, total water use is also low and is estimated at 50 million $\mathrm{m}^{3}$.

\subsubsection{Groundwater irrigation}

There are two different categories of groundwater users: those who are members of village or pump co-operatives and those who make private investments.

\section{Groundwater user groups}

Starting in the 1960s, but increasingly in the 1970s, the government has fostered community-based irrigation based around deep tubewells. Most deep tubewells have discharges in the range of 50-150 l/sec and are often tapping groundwater at least $100 \mathrm{~m}$ below the surface. The majority of wells are outside the boundaries of the surface irrigation systems and are concentrated in the Akhisar and Nif valleys. Typically crops are high value and include tobacco, vegetables, and fruit trees. Total water extractions are estimated at 30 million $\mathrm{m}^{3 /} / \mathrm{year}$ on the basis of 100 wells having a typical discharge of $75 \mathrm{l} / \mathrm{sec}$ and operated for $40-50$ days per year.

\section{Private groundwater users}

Private groundwater exploitation started during the drought of 1989-1994. Many individuals purchased centrifugal pumps to exploit shallow groundwater within the boundaries of surface irrigation systems, and in some cases neighbours formed informal pump groups to purchase a pump and well, and share operating costs at the end of the season. Farmers have kept using these pumps and there has been a recent small increase as some farmers adopt trickle irrigation systems for high-value fruits and vegetables.

The vast majority of private pump owners are within the boundaries of the surface irrigation systems. As such they rely on the seepage and management losses from the surface irrigation system. While there is some evidence that the shallow groundwater table dropped during the drought, it has since recovered and it is assumed that they do not mine groundwater but merely re-use surface water. Their net water use is therefore included in the total surface irrigation volumes. However, official records of surface irrigation shows that only about 70 percent of farmers use surface water and some of those also pump. It is estimated that some 40,000 hectares of land in the command areas of the surface irrigation systems are actually pump-based with only 70,000 hectares relying primarily on canal water. 
A few private pump owners are situated on the fringes of the surface irrigation system or in the area between the Alasehir valley and the main Gediz valley. These are estimated to use some 5 million $\mathrm{m}^{3 / y e a r}$ that is not direct recharge from surface irrigation systems.

\subsection{Municipal water supply}

The Gediz basin has two separate classes of urban and municipal water users: the towns and villages within the basin itself, and a substantial trans-basin diversion of drinking water to Izmir.

\subsubsection{Within-basin use}

There are no accurate records of total water extractions for urban and municipal water consumption in the Gediz basin. All municipal extractions are from groundwater. Based on estimates provided by the different municipalities, it appears that extractions are in the order of 130 million $\mathrm{m}^{3} / \mathrm{year}$. However, much of this returns in the form of wastewater, either percolation into the groundwater or discharge in surface water. Allowing for 20 percent actual consumption, the net municipal extraction within the basin is estimated to be 26 million $\mathrm{m}^{3} / \mathrm{year}$.

Some municipalities also have shown interest in using good-quality spring water for their water supply. In a few cases municipalities have arranged with villages to use a portion of their spring water and agree to compensate them by improving village irrigation systems.

\subsubsection{Izmir use of Gediz water}

The city of Izmir has had a long-standing claim on groundwater within the Gediz basin. There are two main well fields, at Sarikiz in the north of the basin and Goksu near Manisa. Actual consumption data are not available, but lzmir has extracted as much as 108 million $\mathrm{m}^{3} / \mathrm{year}$ from these well fields. Because the water is transferred out of the basin, there is no return flow ${ }^{2}$. An important potential source of additional water for in-basin use is the estimated 50 percent of the water entering the Izmir municipal system which is lost to underground leakage. Since Izmir is on the sea, no reuse of these losses is possible. If the conveyance efficiency of the Izmir piped system were improved, up to 50 million $\mathrm{m}^{3}$ of high-quality groundwater could be left in the Gediz basin annually and used for other purposes.

\footnotetext{
${ }^{2}$ There is a proposal for Izmir to supply irrigators in lower portions of the Gediz basin with treated wastewater. Irrigators are enthusiastic about this because of the very poor quality of the surface water they currently receive. There are concerns, however, about possible high salinity in the treated effluent. At design output, the treatment plant would produce about 880 million $\mathrm{m}^{3} /$ year, roughly equivalent to the entire current use in the basin.
} 


\subsection{Industry}

There are two important industrial areas in the basin. The largest is in the Nif Valley immediately east of Izmir in Kemalpasa municipality. There is also a growing industrial estate in the western edge of Manisa. Industries included ceramics, leather, food processing, metal works and assembly plants.

In both areas groundwater is used for the industries, and each industry must obtain a permit from DSI. However, there are no records of how much water is consumed and it is difficult to make an estimate of total water use.

\subsection{Hydropower}

Between 1970 and 1988, Demirkopru Reservoir was used for hydropower generation throughout the year. Since the drought, however, power generation has been restricted to periods when water is released for irrigation or for flood control and no special releases for hydropower are made.

\subsection{Environmental consumption}

The seaward fringe of the Gediz delta is an important nature reserve and has recently been designated as a Ramsar site to protect rare bird species. Originally the area received excess water from the Gediz River for much of the year, but since 1990, with restrictions on irrigation releases, the reserve suffers from water shortages. The summer months are the critical time for providing water specifically for the nature reserve, since during the winter water is available from the Gediz River before flowing to the sea.

In response to demands to preserve bird habitat, one small channel with a capacity of $0.7 \mathrm{~m}^{3} / \mathrm{sec}$ does now extend from the irrigation system into the nature reserve. However, the channel does not always flow at the maximum rate during the 60 day irrigation season, and so the potential volume of about 4 million $\mathrm{m}^{3}$ per day is not normally provided. One preliminary estimate suggests that to maintain appropriate conditions for freshwater bird habitat, as much as $1.5 \mathrm{~m}^{3 /}$ $\mathrm{sec}$ is required during the 120 days of the summer season, or a total of about 15 million cubic meters. Enlargement of an existing irrigation channel to carry an additional $1 \mathrm{~m}^{3} / \mathrm{sec}$ flow is proposed.

A second component of environmental demand is the water needed for waste conveyance from points of origin within the basin to the sea. In transporting wastes, the flow must provide sufficient velocity to prevent organic compounds and heavy metals, adsorbed on to soil particles, from settling out before reaching the sea, and sufficient dilution to avoid in-stream environmental harm. Obviously, reducing the pollutant loads which must be carried will reduce the quantity of water needed for this purpose.

\subsection{Use patterns}

The total estimated water extraction by the different users is shown in Table 1. 
Table 1: Estimated water use by sector

\begin{tabular}{|c|c|c|c|}
\hline \multirow{2}{*}{ Water User } & \multicolumn{2}{|c|}{$\begin{array}{c}\text { Estimated } \\
\text { consumption }\end{array}$} & \multirow{2}{*}{ Notes } \\
\hline & Imilion $\mathrm{m}^{3}$ & Share & \\
\hline $\begin{array}{l}\text { Surface Water } \\
\text { Large-scale irrigation } \\
\text { Small-scale irrigation } \\
\text { Hydropower } \\
\text { Bird Reserve }\end{array}$ & $\begin{array}{r}550 \\
60 \\
50 \\
0 \\
4\end{array}$ & $\begin{array}{r}62 \% \\
7 \% \\
6 \% \\
.\end{array}$ & $\begin{array}{l}\text { From Demirkopru and Gol Marmara } \\
\text { Alasehir valley } \\
\text { No priority for hydropower } \\
\text { Current releases only: needs more }\end{array}$ \\
\hline $\begin{array}{l}\text { Groundwater } \\
\text { Pump irrigation } \\
\text { Groups } \\
\text { Private irrigators } \\
\text { Urban within the } \\
\text { Basin } \\
\text { Transfer to Izmir City } \\
\text { Industry }\end{array}$ & $\begin{array}{r}30 \\
5 \\
26 \\
108 \\
50\end{array}$ & $\begin{array}{r}3 \% \\
1 \% \\
2 \% \\
12 \% \\
6 \%\end{array}$ & $\begin{array}{l}\text { Only those outside surface irrigation } \\
\text { area } \\
18 \% \text { of extraction, remainder is return } \\
\text { flow } \\
\text { Trans-basin transfer, no return flow } \\
\text { Estimated by DSI }\end{array}$ \\
\hline $\begin{array}{l}\text { Totals } \\
\text { Annual } \\
\text { Summer (4 months) }\end{array}$ & $\begin{array}{l}833 \\
760\end{array}$ & $100 \%$ & \\
\hline
\end{tabular}

\section{Water resources of the Gediz basin}

\subsection{Hydrology}

\subsubsection{Surface water}

The hydrology of the Gediz basin is typically Mediterranean. Precipitation falls between November and April, and peak river flows occur in February or March. Annual precipitation varies from $800 \mathrm{~mm}$ in higher inland areas to about $450 \mathrm{~mm}$ near the cost, with about 80 percent falling in the winter months. Under natural conditions there is a steady decline in stream discharge until May when many of the smaller streams dry up. Summer flows are only present in the Gediz River and its largest tributaries, and even they may be negligible in the peak summer months. Following the irrigation season, the only flows in the Gediz River are from the few larger tributaries plus residual return flows from irrigated areas and industrial and municipal wastewater discharges to the river.

Following the construction of Demirkopru Dam and before the drought, net annual surface water availability in the main basin and the delta is estimated to have been approximately 1,900 million $\mathrm{m}^{3} /$ year. Since 1990 , however, there has been a persistent decline in surface water flows into Demirkopru and water availability has averaged only some 940 million $\mathrm{m}^{3}$ during this period. As some of this flow occurs in winter and is derived from tributaries where there is no storage, there is little difference between annual surface water availability and current demand of about 660 million $\mathrm{m}^{3}$. 


\subsubsection{Groundwater}

Groundwater resources are able to make up some of the potential shortfall in overall water availability. The central part of the basin is an alluvial plain whose groundwater reserve is replenished in most years. Only during the peak of the drought, from 1991 to 1993 , were there reports of declining year-to-year water tables, and they have since recovered.

In the alluvial fan areas on either side of the main valley and in the Nif Valley the situation is more critical. Tubewell-based farmers in the Akhisar area complain of a steady and long-term decline in water tables, and in the Nif Valley the water table is reported to have dropped by $5-8$ meters in the past 10 years as industrial extractions have burgeoned. Springs in the limestone areas are also reported to have declined in the past decade.

The estimated safe annual yield for groundwater in the main part of the valley is estimated to be 160 million $\mathrm{m}^{3} /$ year which is about one-third considerably less than the 219 million cubic meters estimated as being extracted from the main and Nif valleys. Despite the absence of definitive figures, it appears that groundwater use presently exceeds, by a sizeable margin, the sustainable limit.

In the Gediz delta there is little groundwater utilisation, and extraction near the coast is prohibited to prevent salt water intrusion. The groundwater is deep and therefore there are no shallow tubewells.

\subsection{Changing patterns of demand}

The drought had an impact not only on the releases made from Demirkopru but also on changing demand. Rice used to be grown in poorly drained central parts of the basin but has been replaced by cotton, while there has been a steady increase in grape and fruit tree areas as agro-industrial enterprises have grown up to support cash crop agriculture. The trend toward grape cultivation, although partly a response to the growing market for raisins, resulted in decreased demand for irrigation water, and total irrigation deliveries are now only about 70 percent of the pre-drought situation. With a recent surge in interest in drip irrigation by fruit, vegetable and seed corn growers, demand is likely to continue to decline.

In contrast, non-agricultural demand is growing rapidly. The area has a higher than average growth rate because of in-migration from poorer parts of Turkey, and Izmir has promoted industrial development to complement agricultural production. Domestic demand for water has been growing by approximately 2-3 percent a year, industrial demand by as much as 10 percent per year. Given that most non-agricultural consumption of water is from groundwater rather than surface water, aquifer management requires closer attention than surface water with respect to available volumes. 
Figure 3: Estimated population and organic waste load generation, Gediz basin, 1970-2010

Population and Estimated Pollution Loads, 1970-2010

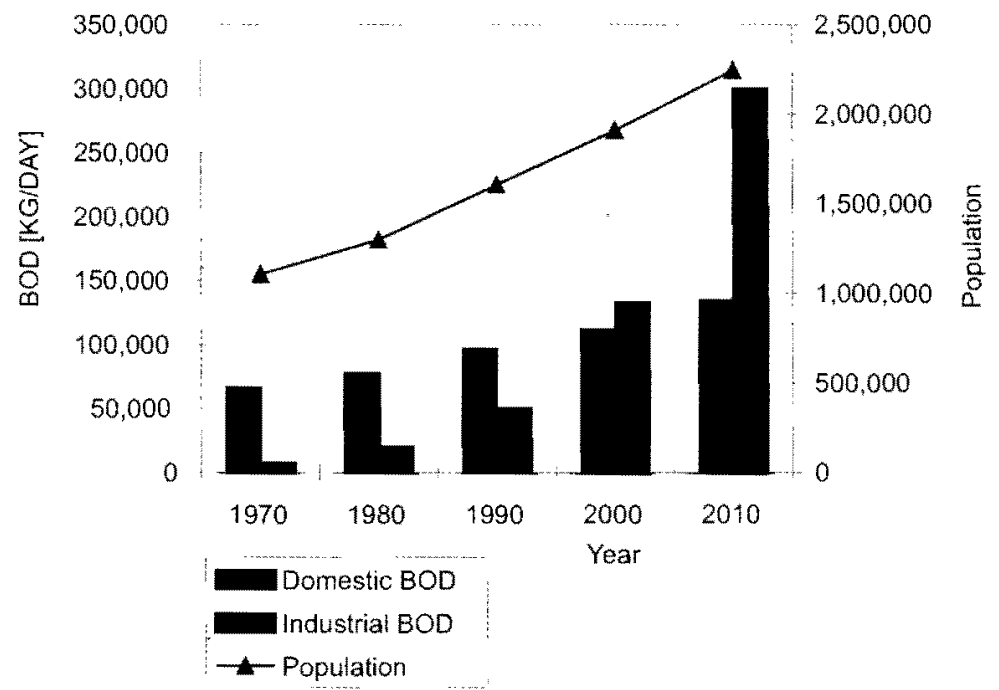

However, an additional demand is arising which is associated with growing concern over water quality, particularly during the peak of the summer season when surface water supplies are limited (see Annex 1). Figure 3 shows actual and estimated growth of basin population between 1970 and 2010 , along with estimated organic load from both domestic and industrial sources. As seen, although domestic load increases modestly along with population growth, industrial load grows exponentially. Note that the chart shows only potential loads and does not take into account the effect of treatment facilities which may or may not exist as of a particular date.

\subsection{Summary}

\subsubsection{Surface water}

Irrigation currently uses a large share of the surface water resources of the basin. Withdrawals total about 660 million $\mathrm{m}^{3}$, with 83 percent of that going to largescale irrigation systems. Current surface water allocation practices are primarily aimed at providing reliable water deliveries to the Irrigation Associations in the large irrigation systems, and this has been achieved with considerable success. Hydropower generation has no priority of its own and uses only water which is to be released for irrigation. A small and probably inadequate allocation of poor quality surface water is currently made for the wetlands in the Gediz delta. 
Heavily-polluted wastewater discharged from urban areas and industries within the basin seriously degrades the quality of surface water in natural channels, particularly in the low-flow summer months. Since water use for these purposes is growing at an estimated rate of six to eight percent per year, this degradation can be expected to worsen unless major efforts at control are made successfully.

\subsubsection{Groundwater}

Groundwater supplies roughly a quarter of basin water use, of which about 16 percent is for irrigation, and the remainder for urban and industrial use. Groundwater supplies nearly all of the water used for these two latter purposes. Irrigation use of groundwater is largely static or declining as less-water intensive crops replace cotton and improved water application technology gains a foothold. Municipal and, particularly, industrial uses are expanding rapidly, however. At present as much as one-quarter of groundwater withdrawal in the basin may be unsustainable overdrafting, and pressure on these aquifers is expected to increase as industrial demand continues to grow.

Much of the water withdrawn for municipal and industrial use within the basin is returned to surface waterways, but in seriously degraded condition. This, in turn, gives rise to a need for additional allocations of surface water for waste load transport and dilution, water which is simply not available at present. The alternative is to improve quality of wastewater discharges significantly at their sources.

\section{Legal, policy, and institutional environment}

\subsection{Water rights}

All natural water resources, except some small privately-owned springs, are vested in the state by the Turkish constitution (Yavuz and Cakmak, 1996). The basic principle governing surface water use rights in Turkey provides that water is a public good which everyone is entitled to use, subject to the rights of prior users. Surface water use is normally free of any obligation to obtain prior authorisation. Conflicts are resolved by first referring to local customary rules and regulations. If the dispute cannot be resolved in this way, rights are settled by court decision. There is no registration system for surface water rights or water use. In large basins where impacts of new diversions are diffuse, this system is generally unable to prevent or resolve conflicts between new and existing claims, and this is leading to serious problems of over-allocation in some basins (Svendsen and Nott, 1997).

Groundwater also is state property. Its management is governed by a 1960 law giving sole authority over the use and protection of groundwater to the General Directorate of State Hydraulic Works (DSI). Drilling a well deeper than 10 meters requires prior approval from DSI, while constructing shallower wells requires only that DSI be notified. Shallow groundwater is thus an open access resource, while deeper aquifers are subject to some controls.

According to the groundwater law, when abstractions "approach the safe output level" of the aquifer, a committee of representatives of "relevant ministries" is to be 
formed to decide on pending and future applications for groundwater utilisation. Frederiksen and Vissia (1998) conclude that enforcement of the groundwater law is weak, which by extension implies that, in practice, the system of groundwater rights created by the current groundwater law is not as effective as it could be.

Rights to both ground and surface water use are thus not formalised. Although they follow roughly the appropriative doctrine of allocation, there are no guarantees of continued access. The principles of the system of water rights outlined above apply in the Gediz basin.

\subsection{Actors}

In an earlier section, five categories of water users in the Gediz basin were identified and their respective water uses outlined. Some of these water users are able to represent their own interests (industries and municipalities), while others may be either many and unorganised (small-system irrigators) or unable for other reasons to represent themselves (ecosystems). In addition there are other State actors such as DSI involved in Gediz basin water management which, while not water users, are important players. The range of basin stakeholders is thus different, and broader, than the group of actual water users. The major ones of these are described below.

\subsubsection{Public agencies}

\section{DSI}

The General Directorate of State Hydraulic Works (DSI) is the main executive agency of the Government of Turkey for the country's overall water resources planning, execution and operation. It was established in 1954 and is currently a part of the Ministry of Energy and Natural Resources. The mandate of the DSI is "to develop water and land resources in Turkey" (DSi, 1995). It is responsible for major irrigation, flood control, drainage, hydropower development, and supplying water to cities with populations over 100,000. DSI centralises most of the state functions involved in planning and developing large-scale water resources.

Until recently, DSI's pollcy has been to manage the irrigation schemes it designs and constructs. Current policy and practice is to transfer schemes to locallybased Irrigation Associations (IAs) to manage. DSI also transfers hydropower and municipal water supply schemes that it designs and constructs to other agencies to operate.

DSI is also responsible for managing and allocating groundwater to prospective users. It does this through the permitting system described in the previous section. Its responsibilities for groundwater quality are limited to monitoring.

DSI maintains 26 regional offices across the country, organised along watershed lines. The Gediz basin lies entirely within one of these regions and is serviced by the regional office in Izmir. 


\section{Ministry of Environment}

The Ministry of Environment (MOE) is the public agency with overall responsible for surface water quality. In spite of this general status, however, its mandate and capacities extend to cover only some of the functions that implementing this responsibility entail. Its major responsibilities include co-ordinating plans among the various public and private agencies involved with protecting the environment, commissioning environmental impact assessments of major water resources projects, and setting standards for and monitoring surface water quality. Actual monitoring and reporting of water quality and wastewater discharges are carried out by provincial offices of MoE. The explicit mandate of the MoE does not extend to groundwater quality. Neither the national nor the provincial offices of MOE possess direct enforcement powers.

\section{Municipalities and villages}

Towns and villages play three important roles in the water resource arena. First they are water users and dischargers of wastewater. There are 19 settlements in the basin with a combined population of 1.35 million. All draw their domestic water supplies from groundwater. Of the 19 , only 3 have completed wastewater sewage systems and treatment plants. The remainder discharge untreated wastewater into the Gediz and tributaries.

The second important role played by towns and villages is that of representing irrigation water users in their areas. They do this (a) through their statutory dominance of the boards of large-scale Irrigation Associations, (b) as owners and operators of municipal irrigation wellfields, and (c) as representatives of the interests of otherwise unorganised farmers irrigating from private wells or small surface water sources who make up parts of their constituencies.

The third role is that of environmental regulation. Municipal and village administrations are responsible for operating water and wastewater treatment plants within their jurisdictions and monitoring the quality of domestic water supplies ${ }^{3}$. They also have some authority to monitor industrial wastewater discharges, although most are not active in this area.

\section{Provinces and districts}

Provincial and district governors, appointed by the Ministry of the Interior in Ankara, are the only authorities with the power to assess fines or issue and enforce prohibitions against violators of water quality regulations. All other actors, including MoE, MoH, DSI, and municipalities, may only report cases that contradict laws for which they are responsible to the provincial or district governor. District governors must secure approval from the provincial governor before taking action. Provincial governors are thus singularly responsible for water quality enforcement proceeding.

${ }^{3}$ The Ministry of Health $(\mathrm{MoH})$ may monitor the quality of drinking water in piped distribution systems at the request of a municipality or village. 


\section{State Planning Organisation}

The state Planning Organisation is an arm of the Prime Ministry which prepares a rolling five-year investment plan for the nation. It is responsible for planning all public capital investment in the country, including investments for water resource development, wastewater treatment, and environmental problem mitigation.

\section{General Directorate of Rural Services}

The General Directorate of Rural Services (GDRS), a part of the Prime Ministry, is responsible for developing small-scale groundwater resources for irrigation, developing surface water sources with flows of less than 500 litres per second for irrigation, on-farm irrigation development, and the construction of rural roads and village water supply systems. GDRS's minor irrigation schemes are transferred to farmers' co-operatives or local governments upon completion. GDRS does not have an operation and maintenance capacity.

\subsubsection{Semi-public or private groups}

\section{Irrigation Associations}

Thirteen irrigation Associations (IAs) were established in the seven large canal irrigation commands in the basin in 1995 under the accelerated irrigation management transfer programme of DSI and have assumed operational control of canal irrigation in those areas. DSI continues to operate the main reservoir and river diversion structures, but operational management below that level is now in the hands of the IAs.

The legal basis for forming IAs is a law allowing the establishment of associations of local governments, and the present governance structure of the IAs is dominated by elected village heads, town mayors, and elected members of local municipal councils. Irrigation Associations are public bodies that enjoy tax exemptions and are non-profit, but are not bound by standard government civil service regulations and financial procedures. Although this system has drawbacks, it does provide valuable links with local government structures. IAs operate the canal systems within their areas, employing hired staff and financing operations and maintenance through fees collected from water users. The 13 IAs collaborate extensively on an informal basis and have discussed the possibility of forming a more permanent association to represent their common interests. They are the most important water users in the basin and retain a strong functional tie to DSI, which provides their bulk water supply and serves as the basin water allocation authority in the absence of a more explicit system of water right allocation.

\section{Other irrigators}

Other irrigation water suppliers and users not encompassed by IAs include towns and villages which have developed well-fields for irrigation supply in their areas, individual farmers and groups of farmers who have invested in irrigation wells, and farmers who employ small surface water diversions in upper parts of the Gediz 
catchment to irrigate crops. There is no formal organisation tying these water users together, though their number is significant. To some extent, local village heads and town mayors are able and generally willing to represent the interests of these irrigators when a need arises. Such representation is not co-ordinated among villages, however, and in general would not be expected to be particularly potent in competition with larger better-organised interests.

\section{Environmental NGOs}

There are many NGOs active in the field environmental conservation in Turkey. A 1995 directory lists 98 of them, and there are others which are not included in the directory. With respect to water-related issues in general, and the Gediz in particular, the following are among the most important.

- Turkish Erosion Control, Reforestation, and Environment Foundation (TEMA). TEMA was established in 1992 with strong business community support. It currently has about 50,000 members and in 1997 operated on a budget of US\$2 million. TEMA publishes a monthly bulletin on environmental issues and every two-years publishes an Environmental Profile of Turkey, which is now also available in English. It enjoys good contacts with the Ministry of Environment and has been instrumental in shaping the new national environmental laws and regulations ${ }^{4}$. It is the most influential of the national environmental NGOS.

- Gediz basin Erosion Control Reforestation and Environment Foundation (GEMA). This NGO has interests similar to those of TEMA but is concerned specifically with the Gediz basin

- Society for the Protection of Wildlife. This society was established in 1975 and works to raise awareness of shrinking populations of various wildlife species, with a special focus on birds. The society works extensively with elementary school children, publishing a newsletter and guidebooks for schools and others. It collaborates with the World Wildlife Fund and other international organisations.

Although concerned with water, none of these organisations place a priority focus on it. Most of NGO activities to date have been concerned with education, awareness raising, and lobbying, with little independent scientific or information collection effort evidenced so far.

\section{Industries}

Although industrial plants are scattered throughout the Gediz basin, the largest concentration is in two Organised Industrial Districts, one in Kemalpasa in Izmir

${ }^{4} \mathrm{DSI}$ has an agreement with TEMA for reforestation of certain catchment areas above DSI reservoirs. 
Province with abut 180 enterprises, and the second near Manisa in Manisa Province with about 50 enterprises. The owners of these industries are organised into several associations which wield considerable political power. These include the Aegean Chamber of Industry, the Businessmen's Association, and the Young Businessmen's Association.

\section{Environmental assemblies}

Local environmental assemblies (Mahall Cevre Kurulu) have recently been formed in several basin areas. Authorised under the Environmental Law, assemblies are broadly constituted, comprising mayors, DSI, the Chamber of Industry, and so on, and are typically chaired by the provincial governor. They meet monthly and are authorised to make fairly influential decisions on issues relating to urban emvironmental quality. Such an authority, chaired by the district governor, exists also for the Kemalpasa Organised Industrial District.

\section{Water and the Poor}

As always, the poor, particularly those living in makeshift and illegal housing on the urban fringe, have the worst access to safe drinking water and sanitation services. Because of more limited mobility, they are also the ones most affected by pollution of the Gediz which they are more likely to use for recreational purposes. Access to irrigation water is determined by access to land, which in turn is also related to wealth, both as a cause and as an effect. Many smallholders do practise very productive agriculture, however, often growing high-value horticultural crops.

\subsection{Essential functions: gaps and overlap}

Burton (1999) has identified 11 essential functions of basin management. A somewhat modified listing of these functions, as they apply in the Gediz basin, crossed with the key actors identified in the previous section is shown in Table 2. These functions are replicated, as appropriate, across four broad categoriessurface water, ground water, wastewater disposal, and agricultural return flows. Cells are marked to indicate an actor which is active in a particular functional area. Information is drawn largely from richly-detailed reports prepared by Harmancioglu et al. $(1999,2000 a, 2000 b)^{5}$.

Several terms require definition. Allocation refers to basin or sub-basin-level division of water among users, including practices relating to the granting of rights to use water. It also includes the supply of bulk quantities of water to major distribution

\footnotetext{
${ }^{5}$ Note that the activity indications contained in the table refer to actual activity in practice, and not nominal responsibility as assigned in statutes. Open circles indicate limited activity, while filled circles indicate more extensive activity. Situations where there is only minor activity might not be indicated in the table. The indications are the collective judgements of the study authors and do not represent formal or official judgements by any of the collaborating organisations.
} 


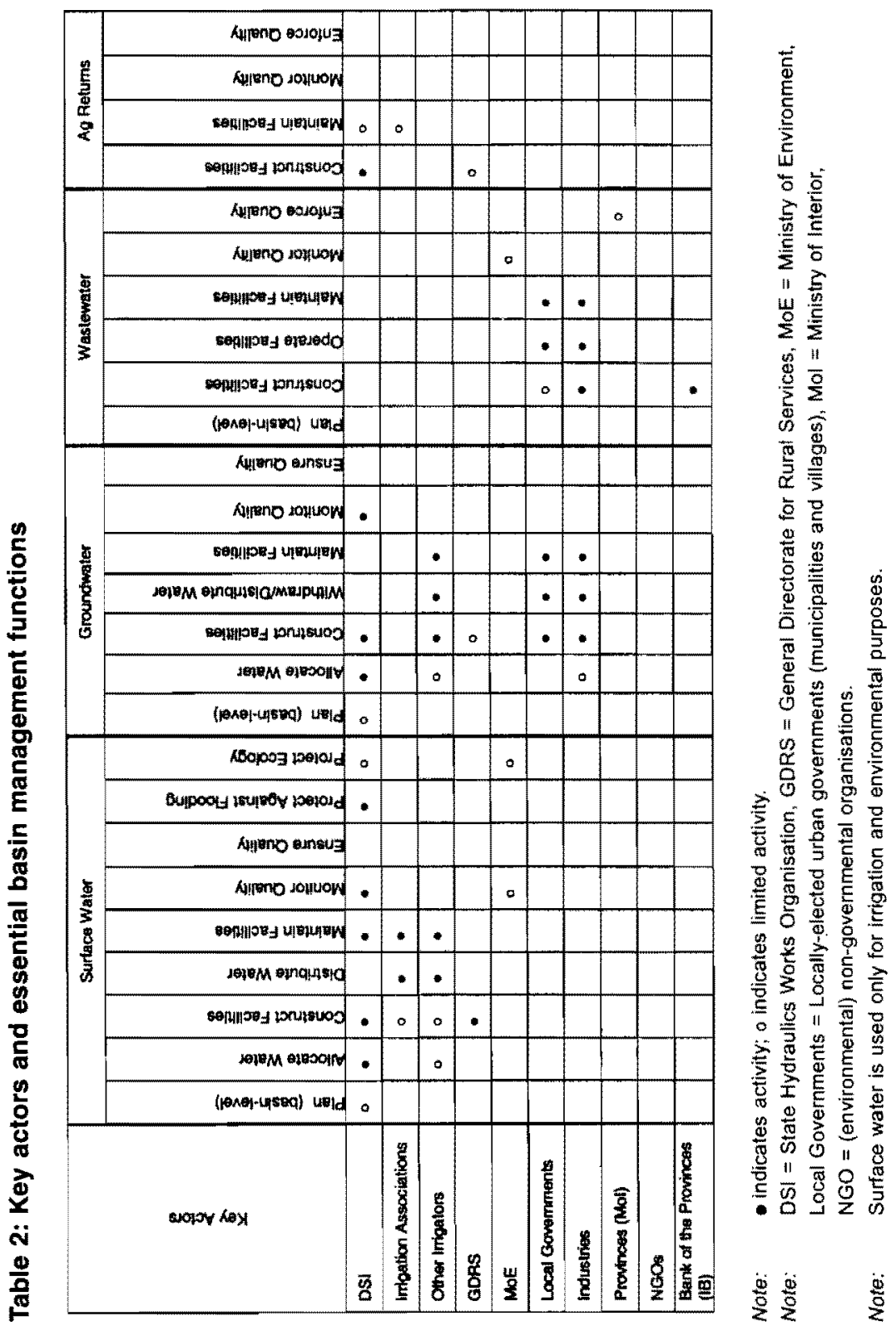


points. Water distribution refers to the more routine practices associated with the regular delivery of water to multiple users. It might also be thought of as provision of a water-related service to users. Monitoring water quality refers to taking measurements, taking and analysing samples, and storing the resulting data. Ensuring water quality is a more active process of investigating deviations from quality standards based on monitoring information, identifying causes, and taking remedial action. Enforcing water quality refers to the process of securing compliance with wastewater quality standards on the part of the discharging municipalities, industries, or agriculturalists.

A number of interesting points emerge from an examination of Table 2, supplemented with background observations.

- There has been very limited planning at the basin level with respect to surface water and virtually none for groundwater and waste disposal ${ }^{6}$. There is no integrated plan which considers both groundwater and surface water availability, nor does existing planning consider water quality, wastewater disposal, current and projected land use, anticipated future demand and return flows, or projected future quantity and quality of water resources.

- Water is allocated, in practice, by a variety of agencies and users operating independently of each other. These include DSI, private surface and groundwater irrigators, and industries. There is no national legal framework for surface water rights and only a rudimentary system of allocating access to groundwater, and both are largely open access resources at present. Although nominal control is stronger for groundwater than for surface water, groundwater is presently the most stressed of the two resources resource. It is also the more desirable of the two, in part because of the poor quality of Gediz surface water, but also because of the relative ease of access provided by groundwater. The current system of registering groundwater withdrawals does not appear to be effective at present at limiting overdrafting which is occurring in certain sub-basins.

- Water quality monitoring takes place, but information is often not available in useful forms to interested parties. DSI operates 14 water quality sampling locations within the Gediz basin, sampling about 35 parameters on a monthly or bi-monthly basis. The information collected remains as pure data in DSI files and is not generally used as a basis for policymaking or decision-making for basin management.

\footnotetext{
${ }^{6} \mathrm{DSI}$ is currently anticipating a new Gediz basin planning exercise. The previous plan was prepared 35 years ago and updated in 1982, but covered only surface water. The groundwater section of the DSI regional office is also planning a new groundwater survey in the near future.
} 
- A single actor, the provincial governor's affice, is empowered to authorise enforcement of breaches of wastewater discharge regulations by banning offending practices or imposing fines. In practice, attempts to process fines or prohibit industrial activities often leads to confrontation between industrialists and public administrators, with the administrators generally lacking the political will and power to make penalties stick. It is very common for files of violation reports to remain unprocessed in the offices of district and provincial governors.

- Ensuring surface water and groundwater quality is not actively practised in the Gediz basin. Ensuring water quality involves conducting follow-up investigations of observed sub-standard water quality to identify its sources and proposing remedies.

- No attention is currently paid to the quality of agricultural return flows. It is sometimes presumed that these flows contribute nitrates to groundwater and nitrates, phosphorus, and organic chemical residues, e.g. from pesticides, to surface water, but there is little hard information on this, nor is any responsible party actively monitoring or assessing the quality and impact of agricultural return flows.

- Agricultural drainage infrastructure is inadequately maintained at present. Drain maintenance receives a lower priority from IAS compared with delivery channel maintenance and DSI has inadequate budget and equipment to fully maintain larger drains. In addition, responsibility for maintaining main drains which serve more than one IA is under dispute by DSI and IAs.

- NGOs have no role in performing essential management functions, but clearly have an important role to play in overall basin governance. This suggests that cataloguing essential functions, while useful, does not constitute, by itself, a sufficient analytic methodology for understanding and diagnosing problems affecting basin governance ${ }^{7}$.

\subsection{Enabling conditions: where problems lie}

The essential functions and actors' roles depicted in Table 2 provide a static view of responsibilities. Additional attributes of well-functioning basin governance systems relate to its dynamics. We term these attributes enabling conditions.

\footnotetext{
The term governance is used in a somewhat different sense here than in Burton's list of essential attributes, of which it is one. Here the term refers to the rules providing the context for muti-actor basin management and the processes and activities engaged in by those actors operating within this set of rules.
} 


\begin{tabular}{|c|}
\hline Enabling Conditions \\
Political Attributes \\
Representation of interests \\
Balanced power \\
Informational Attributes \\
Process transparency \\
Information availability \\
Information accessibility \\
Legal Authority \\
Appropriate institutions \\
Adequate powers \\
Resources \\
Human \\
Financial \\
Institutional \\
Infrastructural
\end{tabular}

Enabling conditions are features of the institutional environment at the basin level that must be present, in some measure, to achieve good governance and management of the basin. These attributes are not specific to any one actor, but apply to all actors and their interactions and comprise necessary (but not sufficient) normative conditions for success. Basic enabling conditions are shown in the box below. A full analysis of these factors is well beyond the scope of this paper. A brief sketch of each in the context of the Gediz basin will be attempted to illustrate the concepts and indicate broad strengths and weaknesses.

\subsubsection{Political attributes}

This is perhaps the most important gap in the current set of enabling conditions. Although some water users are well represented, others are not, and in the arena of political give and take those without representation become losers. Industrialists, for example, have ample financial resources, are well organised, and have ready access to political decision makers. Other irrigators, on the other hand, are unorganised and enjoy representation only through their local village heads. Their interests are rather fragile. Irrigation Asssociations are intermediate. They enjoy multiple connections to the local political establishment by virtue of having a number of village heads and town mayors on their managing committees. In addition they collaborate informally, sharing information and co-ordinating activities. Irrigation Asscciations would benefit by establishing more formal linkages among themselves to allow a single spokesperson to represent them collectively in discussions over basin water allocation, water quality standards, potential irrigation return flow 
restrictions, and so on. Other irrigators could affiliate with such an association and, contributing financially to it, participate in its representational benefits.

The most serious failure of representation at the moment relates to the environment. Although it is nominally represented by the Ministry of Environment, the Ministry is still relatively young and has yet to establish presence and capacity in many areas. For example, it currently has provincial offices in only two of the four provinces covered by the Gediz basin. It also lacks sufficient budget to perform its many duties fully. Moreover, as a government agency, it will always be subject to political pressures and pulis that encourage or inhibit vigorous pursuit of particular water quality issues. Experience from other countries has shown that strong non-governmental organisations (NGOs) rooted in civil society are essential components of the political system surrounding environmental issues. These NGOs serve as advocates for environmental values and for unrepresented future generations. There are several groups with potential to fulfil this role, but at present they provide an ineffective counterweight to other interests.

Just as important as the existence of representational bodies is the need for a rough balance of political power and influence among various interests. When power is one-sided, issues are not aired adequately, and decisions are also onesided. A key to the evolution of a suitable and balanced governance regime for the Gediz basin is further maturation of non-government organisations and associations based in civil society which can advocate for environmental interests.

\subsubsection{Informational attributes}

Another essential enabling condition is the presence in the public domain of accurate and up-to-date descriptive information on water-related issues in the basin, along with open public transaction of decision making processes related to plans, regulations, violations, and sanctions. The first of these stipulations require that information on basin water allocations, reservoir positions, groundwater elevations, water quality conditions, available resources, and so on be a part of the public record. Information collected with public funds should be available to the general public at little or no charge in the interest of sound and democratic public decision making. This disclosure condition applies to intraand inter-departmental information relationships as well as to those with the general public. The second stipulation, transparency of public proceedings, is likewise essential to fair democratic processes. Pent-seeking behaviour requires darkness and privacy to thrive, and conducting regulatory processes in full view of the public is an effective antidote to such practices.

\subsubsection{Legal authority}

Establishing appropriate institutions requires suitable legal authority. This does not appear to the most serious current problem constraining the emergence of an effective governance regime in the Gediz basin. Although improvements can be made, and a number of legislative changes are proposed in the Eighth Five Year Plan, the most important short-term constraints appear to lie in other areas, such 
as balanced political power and providing adequate resources. Over the longer run, however, the legislation of a new legal basis for an effective system of water rights allocation, protection, and transfer will be essential.

\subsubsection{Resources}

Clearly, all four types of resources listed in the box are needed for effective implementation of basin management activities. In a number of the responsible public organisations they are inadequate. In some this constraint may be relaxed by reassigning staff positions from functions which have lost importance to those which are increasingly so. Another potential problem is scattering of resources among a variety of institutions, where each lacks a critical mass to be effective. In a context of co-operation, it is not necessary that resources be consolidated under a single administrative structure for effective implementation. However co-operation and coordination must be effective if a decentralised strategy is to be effective.

\section{Toward solutions}

\subsection{Problem summary}

In this section the hydrologic, policy, and institutional problems identified in earlier sections are brought together and summarised.

\subsubsection{Poor surface water quality}

The most pressing water-related problem facing the Gediz basin presently is the poor and deteriorating quality of its surface water. The deterioration results primarily from the basin's recent rapid growth in population and the even more rapid growth in local industry, coupled with the widespread use of agricultural chemicals in a highly productive agriculture. Failure to control this growing problem at its several sources leads to large requirements for in-stream flows for dilution-flows which are then unavailable for other uses. The problem stems from several sources.

- Weak enforcement. First and foremost, it is the inability of the provincial and district governors, appointed by the Ministry of Interior, to apply and enforce sanctions and penalties on violators of wastewater discharge standards that is responsible for the growing pollution problem. Although monitoring could be improved and standards tightened, the failure to enforce existing standards effectively, on the basis of existing information, sends a powerful signal to polluters that compliance is unnecessary.

- Weak co-ordination. A second cause of deteriorating surfaced water quality is poor co-ordination and co-operation among the three separate agencies responsible for (a) surface water quality monitoring, (b) wastewater discharge monitoring, and (c) enforcement of standards. To some extent this is driven by bureaucratic tussling over turf. In 
addition, the failure of any of the three parties to come forward with effective, inclusive, and forward-looking leadership is a cause.

- Limited availability of data. Because of restricted access, the debate on water quality is poorly informed and emotional rather than scientific, making development of acceptable remedial measures difficult and contentious.

- Haphazard monitoring of wastewater discharges. The most readily identifiable and correctable causes of Gediz pollution are untreated or inadequately treated wastewater discharges from industries, cities, and towns. It is the responsibility of the Ministry of Environment to monitor these discharges and report breaches of standards to the provincial governor. Limited staff, laboratory facilities, and funds currently forestall an adequate monitoring programme.

- Inadequate funding for wastewater treatment plants. Inadequate funding has two components - capital and operating expenses. Several funding windows are available to industries and municipalities for investment capital but a shortage remains. For municipalities, there is little private sector involvement in constructing and operating treatment facilities, in contrast to the case in many other countries. A considerable amount of the funds made available by the state for municipal treatment plant construction have come through the bank of the provinces, but with little expectation of repayment. This makes the discipline of mobilising private capital for such investment difficult or impossible. Inadequate investment in wastewater treatment by the industrial sector relates, in part, to the weak enforcement record of provincial governors. As long as the costs of compliance exceed the costs of non-compliance, this situation is likely to continue.

- Limited public awareness of the problem. Negative effects of surface water pollution include harm to public health, increased costs to other water users, and negative environmental effects, particularly in the Gediz delta. Limited public awareness of the problem and its impacts results in limited public pressure and support for reforms, which in turn affects every single one of the factors outlined above. Causes of limited public awareness include restricted public access to water quality data collected by government agencies, inadequate MOE efforts to publicise water quality problems, and the long gestation period for non-governmental environmental organisations to become effective advocates and spokespersons.

\subsubsection{Unknown groundwater quality}

The extent of possible groundwater contamination, particularly in the Nef Creek watershed, is unknown. Due to coarse alluvial soils and the extensive use of inground holding pits, some wastewater from both urban and industrial sources may 
go into groundwater rather than being disposed of as surface water effluent. The primary cause of this uncertainty is the following.

- Groundwater quality monitoring is not widespread and the results not publicly available, making it difficult to know if significant degradation of groundwater quality is occurring.

This is a significant gap because aquifer pollution is often more difficult and expensive to mitigate than pollution of surface waters. The possibility of contamination gains added significance as a result of the almost total dependence of the basin's population on groundwater for domestic supplies.

\subsubsection{Loosely-controlled allocation among users}

Shallow groundwater is an open-access resource in the Gediz basin, meaning that anyone with physical access to such water can withdraw and use it. Unregulated use of shallow groundwater creates difficulties where there are clear hydrologic linkages between surface water flows, shallow groundwater availability, and deep aquifer conditions. Deep groundwater and surface water, once released from the Demirkopru Reservoir, share this open access characteristic, in part, as well. The result is that some legitimate needs, especially environmental needs, are inadequately met, access of existing users is insecure, and it is difficult to transfer water allocations among users in a rational way. Among the causes are the following.

- Inadequate representation. Interests of some users are not well represented in allocational planning and decision-making. The most salient example is the environment, and, in particular, the needs of the Gediz delta and its rich complement of wildlife.

- Inadequate specification. While water needs in the basin for largescale irrigation and urban use are generally known at present, present use and future requirements for small scale irrigation, the burgeoning industrial sector, and the environment are not well specified in terms of quantity, timing, and quality requirements. This makes allocation decision making difficult.

- Ineffective reporting and record-keeping. While municipal extractions are reasonably well-documented, industrial extractions from groundwater remain largely a matter of conjecture. This makes evaluation of new requests for withdrawal permits difficult. There is likewise no cumulative inventory of the total number of permits issued, the agreed extraction rates, and the depth from which water is extracted, rendering this process even less rigorous and reliable. 


\subsubsection{Over-arching future problems}

In addition to the current problems affecting water allocation and basin governance, there are longer-term problems which will require more fundamental changes in laws, policies, institutions, and practices. Two of the most significant are the following:

- Rudimentary water rights system. The current national system of recording and harmonising rights to use water dates from an earlier simpler day and is not well adapted to a water short environment. It does not provide security for present users, does not allow for or adequately protect environmental uses of water, and does not provide incentives for economy of use or for orderly transfers among sectors.

- Lack of integrated planning. Assessment of basin water resources is currently. separated into ground and surface water components. Because these interact in practice, there is a need to understand the basin as an integrated water resource system. Also, because water quality influences the uses to which water can be put, and gives rise to its own quantitative demands for dilution flows, quantity and quality must also receive joint consideration.

\subsection{Recent strides}

The current situation in the Gediz basin, and at the national level, is dynamic and somewhat fluid. Locally a number of steps have been or are being taken to improve the enforcement of water quality standards and protect the natural environment. Many of these steps began with a Franco-Turkish basin study of the Gediz in the mid-1990s. Although this study was intended to lead to various action programmes, the latter failed to materialise because of lack of co-operation among the different institutions involved ${ }^{8}$. The study did raise awareness of problems and stimulate other initiatives, however.

In 1996, the provincial MoE office conducted a study of polluting industries in Izmir province which resulted in sanctions on 14 firms. In that same year, MoE offices in Izmir and Manisa began a two-year surface water quality sampling exercise in the lower Gediz.

In early 1998, three provincial governors from the Gediz basin, together with MoE and other parties, convened a "co-ordination meeting" for the basin, which led to the establishment of a co-ordinating committee consisting of the directors of the three provincial MoE offices. More recently, this co-ordinating committee was transformed into a permanent body named the Environmental Protection Service Association of Gediz Basin Provinces. This Association was officially authorised by the cabinet of the national government in December 1999 giving it a legal persona. This association has a broader base than eariier initiatives, and, in principle, has

"The study was never formally "accepted" by DSI or MoE. 
considerable power. Since its creation, however, it has lain largely dormant due to lack of resources and the ongoing bottleneck in the enforcement of existing standards and regulations.

At the national level, sentiment for change is reflected in the recently published Eighth Five Year Plan covering the period 2001-2005. The Plan recognises the need for change in the way water is allocated and managed. There is a commitment to introduce new water legislation that will cover such issues as water rights, responsibilities for water allocation, setting and enforcing environmental standards, and consolidating the position of the Irrigation Associations. However, the Plan does not specifically mention basin level water management nor is there any provision for establishing basin level entities that could implement or co-ordination various basin-level activities. Reduction in support for utilisation of fertilisers and agricultural chemicals is a preliminary step toward addressing non-point source pollution problems. Revising water and wastewater standards to comply with EU standards will raise the bar for existing polluters and those in compliance alike.

The Plan does indicate that the private sector will become more involved in various aspects of water, adding an additional set of regulatory challenges to the existing situation and raising the question of the security of rights to water use by less well-represented groups. Until these new initiatives are defined and brought into place, however, current institutional arrangements will continue within the context of rapid growth in demand for water and increasing pressure on water resources from wastewater disposal from urban, industrial and agricultural users.

\subsection{Strengths to build on}

Although the problems faced are formidable, Turkey and the Gediz basin have a number of strengths on which to build an effective basin governance regime. These include the following.

- The premier water resource agency in the country, DSI, is responsible for both ground and surface water, providing a strong base for integrated treatment in the future. This is not the case in many other countries where separate organisations are responsible. Moreover, handing over irrigation management responsibilities to IAs positions it well to take on the role of basin planner and water quality monitor for both ground and surface waters.

- Water quality is squarely identified as an important problem in the Gediz basin. Moreover, while serious, it has not yet reached catastrophic proportions, offering a grace period in which action can be taken. Actors in the basin appear to be responding to the warning signals.

- There is recognition that a number of different actors must be involved in solving water quality problems in the Gediz. It is important to transform this recognition into effective ways of working together, rather than squandering energy and resources in intra-governmental squabbles over bureaucratic turf. 
- Likewise, there is recognition that there are multiple dimensions to water resource management problems - different disciplines, different interests, different uses, ground and surface water, quantity and quality, and so on. Recognising this provides opportunity to deveiop an integrated approach to basin water resource planning and management.

- A new water law is under consideration, offering an opportunity to lay legal groundwork for effective basin management and protection for the Gediz and other water-short basins in the country.

- There is a strong university-based scientific community, e.g. CEVMER and others, providing capability for applied problem-solving research and, where needed, independent scientific assessment.

- There are linkages with international institutions such as IWMI which provide access to international experience of basin governance problems. Moreover, there is a healthy willingness to look outside the country to the experiences of others and a strong interest in harmonising standards, practices, and procedures with those of the European Union.

\subsection{Challenges}

A number of immediate solutions to problems affecting governance and management of water resources in the Gediz basin are self-evident from the listing of problems in section 5.1. In this concluding section, we indicate four important longer-range challenges facing the basin. Addressing these challenges effectively would go a long way toward putting into place a strong, dynamic, and flexible system of basin governance.

\subsubsection{Systematise water rights}

The current rudimentary rights system cannot continue to provide security and flexibility in an era of growing water scarcity. A new system which is fair, flexible, and effective needs to be designed, based on both Turkish and international experience.

\subsubsection{Build representational presence and political muscle}

Some basin water users, such as the natural environment, are not well represented in water-related discussions at present, and there are severe imbalances of political power among the various water users. Fair and equitable governance of basin water resources requires that users and interests be represented in discussion and decision-making fora in a balanced way. NGOs rooted in civil society provide an important voice and advocacy presence for the environment, supplementing the efforts of the MoE, and their emergence as a political force will add balance to 
decision-making and pressure for effective enforcement of sanctions for water quality violations.

\subsubsection{Develop Co-ordinating Mechanisms}

Alternative models for water basin governance exist. At one pole is a comprehensive basin authority, which concentrates power, responsibility, and capacity to implement directly many basin management tasks. At the other pole is a co-ordinating committee which simply provides a forum for discussion and voluntary co-ordination. Between these poles many variations are possible. One thing that is clear is that the present system of compartmentalising water quantity and quality, ground and surface water, and fresh water and wastewater is not an effective base for the future. Mechanisms have to be developed for bringing these components together in a functional integrated system for planning, governance, and management ${ }^{9}$.

A useful first step would be the completion of an integrated assessment of basin water resources of all types and of the present and predicted demands on those resources. High-level political commitment to such an undertaking and strong leadership would be essential. It is equally important that this exercise not be carried out by a single organisation, but that it involves the various agencies, and the different departments within agencies, which have mandates to address water-related issues in the basin. The report produced is only half of the desired output of such a process. The other half is the experience of joint action among agencies and groups to implement the study and the creation of "ownership" of the result by the various stakeholders.

\subsubsection{Involve the private sector}

In many countries, the private sector plays important roles in water resource management. Turkey is well embarked on the devolution of responsibility for managing previously state-operated irrigation systems to locally-based associations. The private sector can also play a major role in providing safe drinking water and effective sanitation services to urban areas. Private sector involvement has a number of advantages, including operational efficiency, ability to mobilise private capital, and access to new technology. To attract such involvement without state guarantees of repayment, firms must have confidence that the principle of paymentfor-service will be honoured and supported by the involved governmental entities. Bringing in such private participation would provide needed capital for wastewater collection and treatment systems and provide wider access to these essential services.

${ }^{9}$ Turkey is not pursuing the concept of basin-wide authorities at present because of the difficult issues posed by important trans-national river basins shared by Turkey and several of its neighbours. The next five-year plan may address this option. 


\section{Bibliography}

Burton, M. 1999. Note on proposed framework and activities. Prepared for the IWMI/DSI/CEVMER Research Programme on institutional Support Systems for Sustainable Management of Irrigation in Water-Short Basins. Izmir.

DSI. 1995. DSI in brief. Ankara.

Fredericksen, H.; and R. Vissia. 1998. Considerations in formulating the transfer of services in the water sector. Colombo, Sri Lanka. International Water Management Institute.

Harmancroğlu, Nilgün; et al. 1999. Institutional support systems project, the Turkey activity, interim report I. CEVMER, Dokuz Eylul University, Izmir. Harmancioğlu, Nilgün; et al. 2000a. Institutional support systems project, the Turkey activity, interim report II. CEVMER, Dokuz Eylul University, Izmir.

Harmancioglu, Nigün; et al. 2000b. Institutional support systems project, the Turkey activity, final report. CEVMER, Dokuz Eylul University, Izmir.

Kayam, Y.; and M. Svendsen. 1999. Small Scale Irrigation in the Gediz basin. Report prepared for the IWMI/GDRS joint research project on Irrigation in the basin Context. Colombo, Sri Lanka: International Water Management Institute.

Svendsen, M.; and G. Nott. 2000. Irrigation management transfer in Turkey: process and outcomes. In Groenfeldt, David and Mark Svendsen, Eds, Case studies in participatory irrigation management. World Bank Institute, Washington, DC.

Wall Street Journal. 4 May 2000.

Yavuz, H.; and E. Cekmak. 1996. Water policy reform in Turkey. Report. DSI and Istanbul University. 


\section{Annex 1. Economic and social context of Turkey}

Turkey is a parliamentary democracy of approximately 65 million people. As of 1997, its population was growing at a rate of 1.5 percent. There is extensive internal migration and rapid urbanisation. At present, 65 percent of the population lives in urban areas, and, while the rural population is shrinking at an annual rate of 0.7 percent, urban population is growing at 2.8 percent per year. At the sub-national level, the country is governed by a mixed system employing both local elections and central government appointments. Population centres (cities, towns, and villages) are governed by locally-elected assemblies or councils with administrations headed by locally-elected mayors. Provinces and districts, while having locally-elected assemblies, are headed by senior civil servants appointed by the Ministry of the Interior. National level policy guidance and instruction is important at all levels and centralised revenue collection makes revenue transfers from national to local levels important and enhances the power of the centre.

Turkey has a strong mixed economy, larger than that of Russia. The present oneyear-old government is taking strong steps to privatise publicly-owned enterprises and introduce other economic reforms under an IMF-backed programme (WSJ, 2000). Economic growth averaged 6.1 percent per year in 1997-98, but shrank at a rate of 6.4 percent for 1999 as a result of the earthquake and the economic restructuring programme. Inflation, however, which has been chronically high for more than two decades, has declined sharply. Turkey hopes to join the European Union, providing a powerful motive across all sectors for harmonising Turkish policies, practices, and standards with those of the EU.

In 1999, agriculture provided just 15 percent of GDP and provided 45 percent of national employment as a result. Agricultural incomes are just one-fifth to one-quarter of those in other sectors. Industry makes up 23 percent of the economy and services 62 percent.

\section{Annex 2. Estimation of future organic loads in Gediz River water}

Based on the data in Table 3 and assuming that in a typical year since the end of the drought, the only surface flows are $75 \mathrm{~m}^{3} / \mathrm{sec}$ released from Demirkopru, $15 \mathrm{~m}^{3}$ / sec released from Gol Marmara, $5 \mathrm{~m}^{3 /} \mathrm{sec}$ as urban wastewater return flows, and a further $5 \mathrm{~m}^{3} / \mathrm{sec}$ from industrial return flows, then the estimated biological oxygen demand $(B O D)$ concentration on a basin-wide basis can be estimated.

Table 3.2 shows these estimates (which are not spatially distributed within different parts of the basin). Irrigation water extractions at different regulators will show different concentrations because of the concentration of BOD generation in urban and industrial areas.

The drought year of 1990 shows a marked increase in potential BOD concentration because irrigation water was only released for 32 days out of a possible 60 days in July and August. In 1992 it would have been higher, on the order of $40-45 \mathrm{~g} \mathrm{~m}^{3}$ released, because irrigation water was only released for 27 days during July and August. By 1997 the potential concentration has dropped despite urban and industrial growth because water is issued for the full 60 days. However, if there are no releases from 
Table 3 : Population, domestic and industrial BOD loads (kg/day), Gediz basin, 1970-2010

\begin{tabular}{|l|r|r|r|r|r|}
\hline & \multicolumn{1}{|c|}{1970} & \multicolumn{1}{|c|}{1980} & 1990 & \multicolumn{1}{|c|}{1997} & \multicolumn{1}{|c|}{2010} \\
\hline Population(1) & 477,449 & 552,767 & 646,467 & 704,844 & 819,945 \\
Uipper & 396,617 & 447,446 & 538,095 & 551,583 & 727,322 \\
Lowar & 242,264 & 298,599 & 421,184 & 512,198 & 696,840 \\
Tolal Basin & $1,106,330$ & $1,298,812$ & $1,605,746$ & $1,768,625$ & $2,244,107$ \\
\hline Oomestic BOD(2) & & & & & \\
Upper & 28,646 & 33,166 & 38,788 & 42,290 & 49,196 \\
Middle & 23,197 & 26,846 & 32,286 & 33,095 & 43,639 \\
Lower & 14,536 & 17,916 & 25,271 & 30,731 & 41,810 \\
Total Basin & 66,380 & 77,929 & 96,345 & 106,116 & 134,646 \\
\hline Industrial BOD (3) & 8,000 & 20,000 & 50,000 & 100,000 & 300,000 \\
\hline Total Estimated BOD & 75,000 & 100,000 & 150,000 & 206,000 & 435,000 \\
\hline
\end{tabular}

Notes: 1. Population data based on State Statistical Office data

2. Domestic BOD at $60 \mathrm{~g} /$ person/day

3. Industrial BOD in 1997 is estimated to equal urban BOD generation.

Past and future industrial BOD values are calculated on a basis on

+10 percent industrial growth rate per annum.

Table 4: Estimated dry season potential BOD loads, Gediz basin, 1970-2010

\begin{tabular}{|l|c|c|c|c|c|}
\hline $\begin{array}{l}\text { Daily surface water } \\
\text { release }\left(\mathrm{m}^{3} / \mathrm{sec}\right)\end{array}$ & 1970 & 1980 & 1990 & 1997 & 2010 \\
\hline $\begin{array}{l}\text { Number of days } \\
\text { BoD (kgday) }\end{array}$ & 60 & 80 & 100 & 100 & 100 \\
\hline $\begin{array}{l}\text { Concentration per unit of } \\
\text { water released }\left(9 / \mathrm{m}^{3}\right)\end{array}$ & 10.8 & 14.5 & 32.6 & 23.8 & 50.3 \\
\hline
\end{tabular}

Demirkopru to dilute wastewater return flows, the situation in 2010 will be at least 20 percent higher than in the peak of the drought of 1992.

These data only refer to BOD. With no reliable estimates of chemical oxygen demand (COD) releases from industry, it is not possible to generate similar estimales, but they will surely show the same growth trends.

In the Menemen portion of the delta, where there is extensive cultivation of soft fruits and vegetables, most farmers rely on groundwater pumping, because the surface water is considered too polluted to use on edible crops. Even the cotton farmers complain of "water that burns", In the tail-end areas downstream of a large tannery complex, water quality is appalling and directly affects the nature reserve. 
Although winter floods, and particularly the near record flood of February 1999, flush out some of the waste that accumulates in periods of low flows, the lack of any regulated minimum flow in the river for non-agricultural purposes means that water quality returns to sub-standard conditions very rapidly. 